\title{
A new method to identify the endangered Pyrenean desman (Galemys pyrenaicus) and to study its diet, using next generation sequencing from faeces
}

\author{
François Gillet $^{\mathrm{a}, \mathrm{b}, c, *}$, Marie-Laure Tiouchichine ${ }^{\mathrm{d}}$, Maxime Galan ${ }^{\mathrm{d}}$, Frédéric Blanc ${ }^{\mathrm{c}}$, \\ Mélanie Némoz ${ }^{c}$, Stéphane Aulagnier ${ }^{\mathrm{b}}$, Johan R. Michaux ${ }^{\mathrm{a}, \mathrm{e}}$ \\ a Department of Life Sciences, Conservation Genetics Unit, University of Liège, 4000 Liège, Belgium \\ b Comportement et Ecologie de la Faune Sauvage (CEFS), Institut National de la Recherche Agronomique, 24 Chemin de Borde Rouge, Auzeville, CS 52627. \\ 31326 Castanet-Tolosan Cedex, France \\ ' Conservatoire d'Espaces Naturels de Midi-Pyrénées, 75 voie du Toec, BP 57611, 31076 Toulouse Cedex 3, France \\ ${ }^{\mathrm{d}}$ CBGP (Centre de Biologie et de Gestion des Populations), UMR INRA/IRD/Cirad/Montpellier SupAgro, Campus international de Baillarguet CS 30016, \\ Montferrier-sur-Lez Cedex, France \\ e CIRAD, Agirs Unit, TA C-22/E-Campus international de Baillarguet, 34398 Montpellier Cedex 5, France
}

\section{A R T I C L E I N F O}

\section{Article history:}

Received 18 April 2015

Accepted 18 August 2015

Handled by Frank E. Zachos

Available online 24 August 2015

\section{Keywords:}

Diet

Faeces

Galemys pyrenaicus

Identification

Next-generation sequencing

\begin{abstract}
A B S T R A C T
The Pyrenean desman (Galemys pyrenaicus) is a small endangered semi-aquatic mammal endemic to the Pyrenean Mountains and to the northern half of the Iberian Peninsula whose ecology and biology are still poorly known. The aim of this study was to identify Pyrenean desman faeces and to analyze its diet from this material using next-generation sequencing methods. We amplified and sequenced a small DNA minibarcode (133 bp) of the COI gene in twenty-four putative faeces samples of Pyrenean desman and successfully identified the species in 16 samples. Other identified species were mammals, birds and amphibians, evidencing the potential application of our methods to a larger panel of taxa.

In the Pyrenean desman faeces, we were able to identify nineteen prey species with a positive match (more than $98 \%$ of identity with a reference sequence) and eleven putative prey species with lower identity scores (90-96\%). The nineteen species belonged to four orders and eleven families among which Trichoptera and Hydropsychidae were the most frequent, respectively. Future improvements could be obtained by extending the reference DNA sequence collection to reach precise identifications over the Desman's range and by increasing the sampling to gain a better knowledge of the local diet of this endangered species. Such information is of great importance to propose the best management measures for its conservation.
\end{abstract}

(c) 2015 Deutsche Gesellschaft für Säugetierkunde. Published by Elsevier GmbH. All rights reserved.

\section{Introduction}

The Pyrenean desman (Galemys pyrenaicus) is a small semiaquatic mammal endemic to the Pyrenean Mountains and to the northern half of the Iberian Peninsula. It is endangered and is currently considered as vulnerable in the IUCN Red List (Fernandes et al.2008) and is legally protected in the four countries encompassing its distribution area (Andorra, France, Portugal and Spain). It has been suffering from habitat loss and fragmentation for decades,

\footnotetext{
* Corresponding author at: Department of Life Sciences, Conservation Genetics Unit, University of Liège, Quartier Vallée 1, Chemin de la Vallée 4, 4000 Liège, Belgium. Tel.: +32 497210869 .

E-mail address: f.gillet@doct.ulg.ac.be (F. Gillet).
}

inevitably impacting its distribution (Nores et al. 2007; Némoz and Bertrand 2008; Gisbert and Garciá-Perea 2014; Charbonnel 2015). The biology and ecology of this species are still poorly known, notably because of its elusive behaviour and its primarily nocturnal activity (Stone 1987; Bertrand 1994). Its distribution area is not even definitively established. However, this information is essential in order to develop the best management strategies for the species (Némoz and Bertrand, 2008).

The nature of trophic interactions is a fundamental topic in ecology and has aroused the attention of biologists for decades. Diet analyses provide key data for understanding animal ecology, evolution and conservation (Shehzad et al. 2012). This knowledge is particularly important when a species is as endangered and elusive in nature as the Pyrenean desman. This species lives in cold and well-oxygenated flowing waters of mountain rivers and is 
well adapted to the aquatic life. The Pyrenean desman is characterized by large webbed hindfeet, a double layered fur, a long tail and a mobile prehensile snout, which make it a specialist in finding and feeding on the larvae of benthonic macroinvertebrates (Palmeirim and Hoffmann 1983; Richard 1986). The diet of the Pyrenean desman has been previously studied either by examining digestive tracts of trapped animals or by analyzing faeces samples (Castién and Gosálbez 1995; Santamarina and Guitian 1988; Santamarina 1993; Trutat 1891; Richard and Vallette Vialard 1969; Fernández-salvador et al. 1998; Bertrand 1994; Puisségur 1935). While these methods have provided some useful information, they are not without flaws. Firstly, the taxonomic resolution based on these approaches cannot exceed the family rank (Bertrand 1994). Secondly, as the Pyrenean desman is a vulnerable species, trapping and killing animals is not appropriate and analyzing faeces is timeconsuming and greatly relies on the experience of the identifier. Indeed, some mistakes can easily occur when identifying the host species especially when faeces are not fresh or have been in contact with water. A recent reliable and non-invasive molecular method was developed to easily distinguish faeces of the Pyrenean desman (Gillet et al. 2015) but the scope of targeted species was limited to other semi aquatic and ecologically related vertebrate species namely the white-throated dipper Cinclus cinclus and the water shrew Neomys fodiens. Therefore, it seems appropriate to propose a more precise and universal method that could clearly identify the Pyrenean desman and its prey, at a finer taxonomic resolution than the family rank.

More recently, several diets based on faeces of a broad panel of mammal species encompassing herbivores, bats, carnivores, and rodents among others, have been successfully analyzed with molecular techniques using DNA barcoding (Soininen et al. 2009; Zeale et al. 2011; Galan et al. 2012; Shehzad et al. 2012; Latinne et al. 2014). The different prey species and plant taxa contained in the faeces are identified by amplifying small and highly variable DNA fragments with universal primers and by using them as barcodes. Among the different DNA regions that have been used for this purpose, the mitochondrial cytochrome oxydase 1 (COI) has been widely used, notably in invertebrate studies (Meusnier et al. 2008; Lees et al. 2010; Virgilio et al. 2010). In addition, the international project Barcode of Life (www.barcoding.si.edu) aims to generate a complete species identification catalogue for all animal kingdom organisms based on the COI gene.

As invertebrates, and particularly macroinvertebrates' benthonic larvae, represent the majority of the diet of the Pyrenean desman, the aim of our study was to use a small COI minibarcode of $133 \mathrm{bp}$ in order to assess the performance of a DNA barcoding technique, using next-generation sequencing, to (1) identify Pyrenean desman faeces, as this will greatly help future studies on this species, especially on its distribution and (2) to analyze its diet at a taxonomic resolution finer than the family rank.

\section{Material and methods}

Twenty-four putative faecal samples of Pyrenean desman were collected in different French Pyrenean localities (Table 1) and preserved in ethanol. DNA from faeces was extracted using the Stool Mini Kit (Qiagen Inc., Hilden, Germany), following the manufacturer's instructions.

In this study, we performed an Ion Torrent PGM sequencing (Life Technologies) following the tagging and multiplexing method developed by (Galan et al. 2012). A 133 bp minibarcode was amplified for each sample using a modified forward primer LepF1 (Hebert et al. 2004): 5'-CCATCTCATCCCTGCGTGTCTCCGACTCAGNNNNNNNATTCHACDAAYCAYAA RGAYATYGG-3', and a modified reverse primer EPT-long-univR (Hajibabaei
Table 1

French localities and departments of the 24 faecal samples used in this study.

\begin{tabular}{lll}
\hline Sample & Locality & Department \\
\hline 1 & Saurat & Ariège \\
2 & Saurat & Ariège \\
3 & Aulus-Les-Bains & Ariège \\
4 & Aulus-Les-Bains & Ariège \\
5 & Gourbit & Ariège \\
6 & Gourbit & Ariège \\
7 & Nescus & Ariège \\
8 & Saint-Paul de Jarrat & Ariège \\
9 & Le Bosc & Ariège \\
10 & Le Bosc & Ariège \\
11 & Aleu & Ariège \\
12 & Sentenac de Sérou & Ariège \\
13 & Sentenac de Sérou & Ariège \\
14 & Boussenac & Ariège \\
15 & Beille & Ariège \\
16 & Beille & Ariège \\
17 & Beille & Ariège \\
18 & Prats-de-Mollo-La-Preste & Pyrénées-Orientales \\
19 & Audressein & Ariège \\
20 & Saint-Michel & Pyrénées-Atlantiques \\
21 & Agnos & Pyrénées-Atlantiques \\
22 & Montségur & Ariège \\
23 & Ansignan & Pyrénées-Orientales \\
24 & Tramezaïgues & Hautes-Pyrénées \\
\hline & & \\
& &
\end{tabular}

et al. 2011): 5'-CCTCTCTATGGGCAGTCGGTGATNNNNNNNACTATAAAARAAAATYTDAYAAA DGCRTG-3'. The $5^{\prime}$ parts of the primers were modified by the addition of individual-specific MIDs (Multiplex IDentifiers NNNNNNN), consisting in a short $7 \mathrm{bp}$ sequence and adaptors required for the emPCR and the Ion Torrent sequencing. By using combinations of different forward and reverse MIDs sequences, several hundred samples can be multiplexed on the same sequencing run, and the sequences can be recognized after sequencing where all the PCR products from the different samples are mixed together. In this study, the 24 faecal samples were multiplexed with samples from other projects. PCR amplification was performed twice for each faecal sample and following the procedure detailed in Galan et al. (2012). Briefly, PCRs were carried out in a $10 \mu \mathrm{l}$ reaction volume using $5 \mu \mathrm{l}$ of $2 \times$ QIAGEN Multiplex Kit (Qiagen, Hilden, Germany), $0.5 \mu \mathrm{M}$ of each primer, and $1 \mu \mathrm{l}$ of DNA extract. The PCR conditions consisted in an initial denaturation step at $95^{\circ} \mathrm{C}$ for $15 \mathrm{~min}$, followed by 40 cycles of denaturation at $94{ }^{\circ} \mathrm{C}$ for $30 \mathrm{~s}$, annealing at $45^{\circ} \mathrm{C}$ for $45 \mathrm{~s}$, and extension at $72^{\circ} \mathrm{C}$ for $30 \mathrm{~s}$, followed by a final extension step at $72{ }^{\circ} \mathrm{C}$ for $10 \mathrm{~min}$. After PCR pooling ( $4 \mu \mathrm{l}$ per strong PCR amplification products and $7 \mu \mathrm{l}$ per lighter ones) and size selection by gel excision, the amplicon libraries were sequenced by the company Genes Diffusion (Douai, France) on a Ion Torrent PGM system using a Ion 316 Chip version 2 (LifeTechnologies).

The sequences were sorted by using the SESAME barcode software (SEquence Sorter \& AMplicon Explorer) (Piry et al. 2012). These sequences were compared with published sequences available in the BOLD database (Ratnasingham and Hebert 2007). Sequences that had a unique best-hit with an identity score greater or equal to $98 \%$ were considered to be positive matches. Identification results are expressed as the number of positive samples for each taxon (order, family and species ranks) and the matching score of species with the database.

\section{Results}

All 24 faecal samples were successfully amplified and a total of 301,369 reads were obtained among which 229,557 were correctly assigned to the 24 samples. Sixteen samples (165,660 reads (70\%)) belonged to the Pyrenean desman with 96,314 reads (58\%) assigned to the desman itself and 69,346 reads (42\%) assigned to 
Table 2

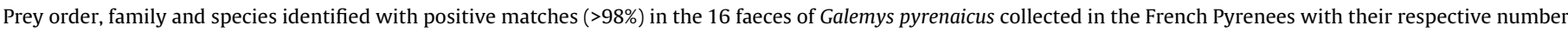
of positive samples (in brackets for orders and families).

\begin{tabular}{|c|c|c|c|}
\hline Order & Family & Species & Number of positive samples \\
\hline \multirow{2}{*}{$\begin{array}{l}\text { Diptera } \\
(2)\end{array}$} & Simulidae (1) & Simulium argyreatum & 1 \\
\hline & Tipulidae (1) & Tipula maxima & 1 \\
\hline \multirow{3}{*}{$\begin{array}{l}\text { Ephemeroptera } \\
\text { (9) }\end{array}$} & Baetidae & Baetis muticus & 1 \\
\hline & (6) & Baetis rhodani & 6 \\
\hline & Heptageniidae (6) & Rhithrogena sp & 6 \\
\hline \multirow{6}{*}{$\begin{array}{l}\text { Plecoptera } \\
\text { (11) }\end{array}$} & Leuctridae & Leuctra aurita & 1 \\
\hline & $(3)$ & Leuctra pseudocylindrica & 2 \\
\hline & Nemouridae & Protonemura intricata & 1 \\
\hline & (3) & Protonemura meyeri & 2 \\
\hline & Perlidae & Dinocras cephalotes & 2 \\
\hline & $(6)$ & Perla marginata & 5 \\
\hline \multirow{8}{*}{$\begin{array}{l}\text { Trichoptera } \\
\text { (16) }\end{array}$} & \multirow{5}{*}{$\begin{array}{l}\text { Hydropsychidae } \\
\text { (13) }\end{array}$} & Annitella thuringica & 1 \\
\hline & & Hydropsyche dinarica & 7 \\
\hline & & Hydropsyche instabilis & 2 \\
\hline & & Hydropsyche siltalai & 2 \\
\hline & & Hydropsyche tenuis & 2 \\
\hline & Limnephilidae (1) & Potamophylax cingulatus & 1 \\
\hline & Odontoceridae (2) & Odontocerum albicorne & 2 \\
\hline & Philopotamidae (1) & Philopotamus montanus & 1 \\
\hline
\end{tabular}

Table 3

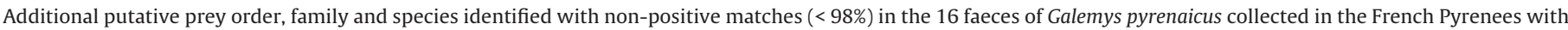
their respective number of positive samples (in brackets for orders and families) and matching score of species with the database.

\begin{tabular}{|c|c|c|c|c|}
\hline Order & Family & Species & Number of positive samples & Percentage of identity \\
\hline Amphipoda (8) & Gammaridae (8) & Gammarus fossarum & 8 & $90 \%$ \\
\hline Coleoptera (1) & Carabidae (1) & Bembidion articulatum & 1 & $92 \%$ \\
\hline Diptera (1) & Thaumaleidae (1) & Androprosopa gillespiae & 1 & $92 \%$ \\
\hline \multirow{4}{*}{$\begin{array}{l}\text { Ephemeroptera } \\
\text { (12) }\end{array}$} & Baetidae (5) & Baetis alpinus & 5 & $94-95 \%$ \\
\hline & Ephemerellidae (5) & Ephemerella mucronata & 5 & $90 \%$ \\
\hline & Heptageniidae & Ecdyonurus venosus & 3 & $96 \%$ \\
\hline & (7) & Epeorus sylvicola & 4 & $91-92 \%$ \\
\hline \multirow{4}{*}{$\begin{array}{l}\text { Plecoptera } \\
(14)\end{array}$} & Nemouridae & Nemoura uncinata & 2 & $96 \%$ \\
\hline & $(5)$ & Protonemura auberti & 3 & $91-92 \%$ \\
\hline & Notonemouridae (2) & Halticoperla tara & 2 & $91 \%$ \\
\hline & Perlodidae (10) & Perlodes microcephalus & 10 & $90-91 \%$ \\
\hline
\end{tabular}

its prey. The remaining 8 samples were assigned to other host species: three samples belonged to the water shrew Neomys fodiens (22,268 reads) and the other were respectively assigned to a species of Rattus (17,257 reads), the edible dormouse Glis glis (9170 reads), Daubenton's bat Myotis daubentonii (7499 reads), the common blackbird Turdus merula (3531 reads) and the fire salamander Salamandra salamandra (4172 reads).

The proportion of items obtained twice in the PCR duplicates for the same DNA extract was computed as the percentage of repeatability. Repeatability of the results reached $100 \%$ when only host species were considered, $86 \%$ when only prey species were considered and $89 \%$ when all species were considered.

The diet analysis of the 16 Pyrenean desman faeces led to the identification of 19 species $(17,684$ reads with a score $\geq 98 \%)$ and 11 additional putative species $(51,662$ reads with a score of 90 to $96 \%)$.

The 19 validated species belonged to four orders (Diptera, Ephemeroptera, Plecoptera and Trichoptera) and 11 families (two for Diptera and Ephemeroptera each, three for Plecoptera and four for Trichoptera). The number of positive samples for orders, families and species are displayed in Table 2. The most frequent order was Trichoptera (16 positive samples), which included the most frequent family and species, Hydropsychidae (13 positive samples) and Hydropsyche dinarica (7 positive samples) respectively.

The 11 putative species belonged to five orders (Amphipoda, Coleoptera, Diptera, Ephemeroptera and Plecoptera) and 9 families (one for Amphipoda, Coleoptera and Diptera, three for
Ephemeroptera and three for Plecoptera) (Table 3). The most frequent orders were Plecoptera (14 postive samples) and Ephemeroptera (12 positive samples), the most frequent family was Perlodidae (Plecoptera) (10 positive samples) and the most frequent species was Perlodes microcephalus (Perlodidae) (10 positive samples).

\section{Discussion}

The amplification of a COI minibarcode successfully provided the identification of both the Pyrenean desman and its prey species in 16 faecal samples. As no predator-specific blocking probe was used in this study, these results confirm the relevance of using this genetic marker with the NGS sequencing method in diet assessments (Piñol et al. 2014). Interestingly, in addition to the Pyrenean desman and its prey, the COI fragment used in this study also led to the identification of other host species including one bird and one amphibian. This demonstrates the potential of the primers used in this study to amplify a larger panel of host species from faecal samples than previously reported (Gillet et al. 2015). These results also show the difficulty of identifying Pyrenean desman faeces in the field by morphological criteria and the risk of confusion with faeces from other species living in the same habitat, as was previously reported (Gillet et al. 2015).

This study also allowed us to unambiguously identify 19 prey species of the Pyrenean desman, with an additional 11 putative species displaying identity scores varying from 90 to $96 \%$. This is 
the first study to give information on the diet of the Pyrenean desman at the species level. The 19 validated species belonged to four orders and eleven families of invertebrates which are consistent with the results of previous studies (Santamarina and Guitian 1988; Santamarina 1993; Bertrand 1993, 1994; Castién and Gosálbez 1995). The most frequent family and species were Hydropsychidae and Hydropsyche dinarica respectively. Even though our sampling is smaller, this result confirms previous findings concerning the preeminence of Hydropsychidae in the diet of the Pyrenean desman (Santamarina and Guitian 1988; Santamarina 1993; Bertrand 1993, 1994). The other most frequent species, Baetis rhodani, Rhithrogena $s p$. and Perla marginata, as well as the majority of the macroinvertebrate larvae species identified in this study are also rheophile, therefore confirming the specialized diet of the Pyrenean desman as previously suggested (Bertrand 1994; Santamarina and Guitian 1988; Santamarina 1993).

Even though a positive match could not be reached for the additional putative species, there is a fair chance that a majority of them could be part of the diet of the Pyrenean desman, especially Baetis alpinus, Ecdyonurus venosus, Nemoura uncinata and Perlodes microcephalus which are common species in the French Pyrenees (http:// www.opie-benthos.fr/). The presence of Coleoptera and Gammaridae (Amphipoda) is not surprising as they were previously reported in the diet of the Pyrenean desman (Santamarina 1993; Bertrand 1994).

\section{Conclusion}

In this study, a diet analysis from putative faecal samples of the Pyrenean desman using DNA barcoding with the Ion Torrent PGM sequencing method provided high-resolution identification of both the Pyrenean desman and its prey as well as other host species belonging to different classes. These results therefore potentially extend the methods used in this study to a broader panel of taxa.

Out of 16 Pyrenean desman faecal samples we were able to identify 19 species with a positive match ( $\geq 98 \%$ match with database), and 11 additional putative species with lower matching scores (90-96\%). More precise identifications should be obtained for these species in the future after building a reference collection of invertebrate species collected in the French Pyrenees. The sequencing of these species could really improve the study of the diet of the Pyrenean desman and the distribution of its main prey at the scale of the whole Pyrenees chain.

As half of the identified species were found only once in our samples, the study of a larger number of faeces could provide a much broader list of prey of the Pyrenean desman. This would also allow studying potential changes of the diet in time and space which could greatly improve the future conservation of this endangered species.

\section{Acknowledgements}

We thank the following organizations who collected faeces samples: Association des Naturalistes de l'Ariège, Conservatoire d'Espaces Naturels d'Aquitaine, Conservatoire d'Espaces Naturels de Midi-Pyrénées, Fédération Aude Claire, Fédération des Réserves Naturelles Catalanes, Groupe de Recherche et d'Etude pour la Gestion de l'Environnement, Office National de la Chasse et de la Faune Sauvage, Office National des Forêts, Parc National des Pyrénées. We thank also Sylvain Piry for his help with the bioinformatic analysis using SESAME barcode.

This study is part of the "Plan National d'Actions en faveur du Desman des Pyrénées" and the LIFE+ Desman (LIFE13NAT/FR/000092) which are coordinated by the Conservatoire d'Espaces Naturels de Midi-Pyrénées (CEN-MP) and are financially supported by the following structures: European Union Funding Network (ERDF and LIFE+), Agence de l'eau Adour-Garonne, Agence de l'eau Rhone-Méditerranée-Corse, DREAL Aquitaine, Midi-Pyrénées, and Languedoc-Roussillon, Conseil Régional Aquitaine, Midi-Pyrénées and Languedoc-Roussillon, Conseil Général des Pyrénées-Atlantiques, de l'Aude et des Pyrénées-Orientales, EDF, SHEM, Patagonia, Parc National des Pyrénées, ANRT (Association Nationale de la Recherche et de la Technologie). F. Gillet is supported by a French research fellowship provided by the ANRT ("bourse CIFRE").

\section{References}

Bertrand, A., 1993. Découvrir le Desman des Pyrénées. Ed. A.N.A., pp. 32.

Bertrand, A., 1994. Répartition géographique et écologie alimentaire de desman des pyrénées G. pyrenaicus dans les Pyrénées françaises. Diplôme Universitaire de Recherche, Toulouse, pp. 217.

Castién, E., Gosálbez, J., 1995. Diet of Galemys pyrenaicus (Geoffroy, 1811) in the North of the Iberian peninsula. Netherlands J. Zool. 45 (3-4), 422-430.

Charbonnel, A., (Thèse de doctorat) 2015. Influence multi-échelle des facteurs environnementaux dans la répartition du Desman des Pyrénées (Galemys pyrenaicus) en France. l'Université de Toulouse, pp. 245.

Fernandes, M., et al., 2008. Galemys pyrenaicus. IUCN Red List of Threatened Species. Version 2013.2, Available at: www.iucnredlist.org

Fernández-salvador, R., et al., 1998. Feeding habits of the Iberian desman, Galemys pyrenaicus. Euro-American Mammal Congress, Santiago de Compostela (Spain).

Galan, M., Pagès, M., Cosson, J.-F., 2012. Next-generation sequencing for rodent barcoding: species identification from fresh, degraded and environmental samples. PLoS ONE 7 (11).

Gillet, F., et al., 2015. PCR-RFLP identification of the endangered Pyrenean desman, Galemys pyrenaicus (Soricomorpha, Talpidae), based on faecal DNA. Mammalia, Available at: http://www.degruyter.com/view/j/mamm.ahead-of-print/ mammalia-2014-0093/mammalia-2014-0093.xml (accessed 01.11.14).

Gisbert, J., Garciá-Perea, R., 2014. Historia de la regresión del desmán ibérico Galemys pyrenaicus (É. Geoffroy Saint-Hilaire, 1811) en el Sistema Central (Península Ibérica). Munibe Monographs Nature Series.

Hajibabaei, M., et al., 2011. Environmental barcoding: a next-generation sequencing approach for biomonitoring applications using river benthos. PLoS ONE 6 (4), e17497, Available at: http://www.pubmedcentral.nih.gov/ articlerender.fcgi? artid=3076369\&tool=pmcentrez\&rendertype=abstract (accessed 07.11.13).

Hebert, P.D.N., et al., 2004. Ten species in one: DNA barcoding reveals cryptic species in the neotropical skipper butterfly Astraptes fulgerator. PNAS 101 (41).

Latinne, A., et al., 2014. Diet analysis of Leopoldamys neilli, a cave-dwelling rodent in southeast asia, using next-generation sequencing from feces. J. Cave Karst Stud. 76 (2), 139-145, Available at: http://caves.org/pub/journal/PDF/v76/ cave-76-02-139.pdf (accessed 25.02.15)

Lees, D.C., et al., 2010. DNA mini-barcodes in taxonomic assignment: a morphologically unique new homoneurous moth clade from the Indian Himalayas described in Micropterix (Lepidoptera, Micropterigidae). Zool. Scr. 39 (6), 642-661, Available at: http://doi.wiley.com/10.1111/j.1463-6409.2010. 00447.x (accessed 14.11.13).

Meusnier, I., et al., 2008. A universal DNA mini-barcode for biodiversity analysis. BMC Genomics 9, 214, Available at: http://www.ncbi.nlm.nih.gov/pubmed/ 18474098 (accessed 07.11.13).

Némoz, M., Bertrand, A., 2008. Plan National d'Actions en faveur du Desman des Pyrénéés (Galemys pyrenaicus), 2009-2014. Société Française pour l'Etude et la Protection des Mammifères/Ministère de l'Ecologie, de l'Energie, du Développement Durable et de l'Aménagement du Territoire, 1.

Nores, C., Queiroz, A.I., Gisbert, J., 2007. Galemys pyrenaicus, (E. Geoffroy Saint-Hilaire, 1811). In: Palomo, L., Gisbert, J., Blanco, J. (Eds.), Atlas y libro rojo de los mamíferos terrestres de España. Dirección General para la Biodiversidad - SECEM - SECEMU, Madrid, pp. 92-98.

Palmeirim, J.M., Hoffmann, S.H., 1983. Galemys pyrenaicus. Mamm. Species 207 $1-5$.

Piñol, J., et al., 2014. A pragmatic approach to the analysis of diets of generalist predators: the use of next-generation sequencing with no blocking probes. Mol. Ecol. Resour. 14 (1), 18-26, Available at: http://www.ncbi.nlm.nih.gov/ pubmed/23957910 (accessed 10.02.15).

Piry, S., et al., 2012. $|\mathrm{SE}| \mathrm{S}|\mathrm{AM}| \mathrm{E} \mid$ Barcode: NGS-oriented software for amplicon characterization - application to species and environmental barcoding. Mol. Ecol. Resour. 12 (6), 1151-1157, Available at: http://www.ncbi.nlm.nih.gov/ pubmed/22823139 (accessed 30.03.15).

Puisségur, C., 1935. Recherches sur le Desman des Pyrénées. Bull. Soc. Hist. Nat. Toulouse 67, 163-227.

Ratnasingham, S., Hebert, P.D.N., 2007. BOLD: The Barcode of Life Data System (www.barcodinglife.org). Mol. Ecol. Notes 7, 355-364.

Richard, P.B., 1986. Les Desman des Pyrénées, un mammifère inconnu à découvrir. Science et Découvertes, Ed., Le Rocher, Monaco, 118 pp.

Richard, P.B., Vallette Vialard, A., 1969. Le Desman des Pyrénées (Galemys pyrenaicus): premières notes sur sa biologie. La Terre et la Vie 116 (3), 225-245. 
Santamarina, J., 1993. Feeding ecology of a vertebrate assemblage inhabiting stream of NW Spain (Riobo; Ulla basin). Hydrobiologia 252 (2), 175-191, Available at: http://link.springer.com/10.1007/BF00008154

Santamarina, J., Guitian, J., 1988. Quelques données sur le régime alimentaire du desman (Galemys pyrenaicus) dans le nord-ouest de l'Espagne. Mammalia 52 (3).

Shehzad, W., et al., 2012. Carnivore diet analysis based on next-generation sequencing: application to the leopard cat (Prionailurus bengalensis) in Pakistan. Mol. Ecol. 21 (8), 1951-1965, Available at: http://www.ncbi.nlm.nih. gov/pubmed/22250784 (accessed 28.03.14)

Soininen, E.M., et al., 2009. Analysing diet of small herbivores: the efficiency of DNA barcoding coupled with high-throughput pyrosequencing for deciphering the composition of complex plant mixtures. Front. Zool. 6, 16, Available at: http://www.pubmedcentral.nih.gov/articlerender.

fcgi? artid=2736939\&tool=pmcentrez\&rendertype=abstract (accessed 17.12.14).
Stone, R.D., 1987. The activity pattern of the Pyrenean desman (Galemys pyrenaicus) (Insectivora: Talpidae), as determined under natural condition. J. Zool. Lond. 213, 95-106.

Trutat, E., 1891. Essai sur l'histoire naturelle du Desman des Pyrénées. Douladoure-Privat, Toulouse, pp. 107.

Virgilio, M., et al., 2010. Comparative performances of DNA barcoding across insect orders. BMC Bioinformatics 11, 206, Available at: http://www.pubmedcentral. nih.gov/articlerender.

fcgi?artid=2885370\&tool=pmcentrez\&rendertype=abstract

Zeale, M.R.K., et al., 2011. Taxon-specific PCR for DNA barcoding arthropod prey in bat faeces. Mol. Ecol. Resour. 11 (2), 236-244, Available at: http://www.ncbi. nlm.nih.gov/pubmed/21429129 (accessed 09.03.15). 